\title{
DISSERTAÇÕES
}

\section{Origens do espiritismo no Brasil: diálogo, razão e resistência no início de uma experiência (1850-1914)}

Paulo César da Conceição Fernandes

Curso: Mestrado em Sociologia

Data da defesa: 27 de maio de 2008

Orientador: Prof. Dr. Eurico Antônio Gonzalez Cursino dos Santos

\section{Resumo}

O espiritismo é uma doutrina surgida na França durante o século XIX. Seus principais postulados são: a imortalidade da alma, a possibilidade de nos comunicarmos com os mortos e a reencarnação. Foi exposta pela primeira vez por Allan Kardec, pseudônimo do pedagogo lionês Hippolyte-Léon Denizard Rivail, que seria o principal responsável por sua divulgação e também autor de obras sobre o tema. Depois de uma história conturbada em solo europeu, devido ao caráter controverso de seus conceitos, o espiritismo chegou ao nosso País e aqui se fixou em rápida propagação. $\mathrm{O}$ objetivo desta pesquisa é entender a relação entre essa doutrina e o Brasil expressa no conjunto de algumas conseqüências socioculturais que emanaram das origens desse contato. Procura-se compreender, também, o espiritismo qua talis, suas influências, sua história e seus principais conceitos. Busca-se, assim, responder algumas perguntas que orientam este trabalho, como: O que é o espiritismo? Qual é a sua história? Por que e por quem o espiritismo foi aqui recebido? Quais mudanças o espiritismo experimentou ao vir para cá? Ele contribuiu ou contribui de alguma forma para a cultura (religiosa) de nossa 
terra? Concluiu-se que ambos, o Brasil e o espiritismo, acabaram por se influenciar mutuamente. Em alguns momentos, tais trocas não vieram de forma pacífica e cada lado procurou apresentar suas "resistências" em meio ao "diálogo" que se estabelecia. Entretanto, uma síntese se impôs e o resultado é um espiritismo mais brasileiro e um Brasil que aprendeu a aceitar o espiritismo, em um processo que começou durante o século XIX, mas que se mostra presente até os nossos dias.

Palavras-chave: sociologia; história; sociologia da religião; sociologia da cultura; sociologia do conhecimento; espiritismo; espiritismo no Brasil. 